\title{
Discovering the Old Dubrovnik Cathedrals: Stone Fragments Analysis, Cataloguing and Structured Terminology Development in Digital Environment
}

Zlodi, Goran; Zeman, Maja; Marinković, Ana; Marušić, Matko Matija

Source / Izvornik: MIPRO 2021 44th International Convention Proceedings, 2021, 788 - 793

Conference paper / Rad u zborniku

Publication status / Verzija rada: Published version / Objavljena verzija rada (izdavačev PDF)

Permanent link / Trajna poveznica: https://urn.nsk.hr/urn:nbn:hr:131:243400

Rights / Prava: In copyright/Zaštićeno autorskim pravom.

Download date / Datum preuzimanja: 2023-04-26

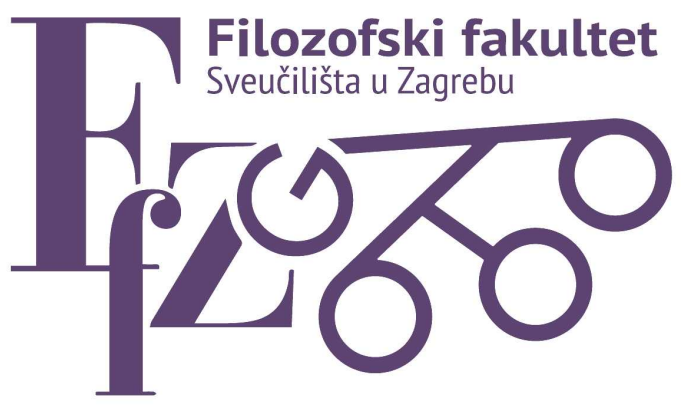

\section{Repository / Repozitorij:}

ODRAZ - open repository of the University of Zagreb Faculty of Humanities and Social Sciences
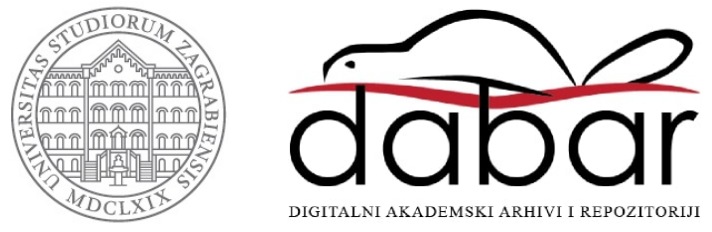


\title{
Discovering the Old Dubrovnik Cathedrals: Stone Fragments Analysis, Cataloguing and Structured Terminology Development in Digital Environment
}

\author{
Goran Zlodi*, Maja Zeman**, Ana Marinković**, Matko Matija Marušić*** \\ * University of Zagreb, Faculty of Humanities and Social Sciences / Department of Information and Communication, \\ Zagreb, Croatia \\ ** University of Zagreb, Faculty of Humanities and Social Sciences / Department of Art History, Zagreb, Croatia \\ *** Independent scholar, Zagreb, Croatia \\ gzlodi@ffzg.hr
}

\begin{abstract}
The research and educational project Discovering the Old Dubrovnik Cathedrals was launched in 2015. Its activities were focused on the study of archaeological finds originating from the site of two consecutive medieval cathedral buildings under the actual Baroque Cathedral in Dubrovnik. The archaeological excavations at the site were undertaken after the earthquake of 1979, and the resulting finds have not been studied since. The primary activity of the educational project that so far involved over 40 students was the study of stone and glass fragments, as well as fragments of wall paintings and pottery. Out of approx. 3000 stone fragments, 250 were selected for detailed cataloguing, analysis and indexing. A metadata record was created for each object and each record was accompanied by multiple photographic representations of the fragment. Whole-part relationships between records allow the structuring and simulation of certain architectural units (e.g. the Romanesque ambo). Another important result of the project is the development of structured terminology via multilingual thesaurus (equivalence, associative and hierarchical relationships have been established among concepts). The aim of the article is to present an application of data processing in the field of digital art history and in the broader context of digital humanities.
\end{abstract}

Keywords - digital humanities; digital art history; Dubrovnik cathedral; archaeological heritage; Middle Ages; database; cataloguing; thesaurus

\section{INTRODUCTION}

The project "Discovering the Old Dubrovnik Cathedrals" has been underway since 2015. The fundamental activities of this project are expert analysis and presentation of the movable monuments and archaeological finds which were discovered in the 1980s during excavations of the ground beneath the Dubrovnik Cathedral, a monument protected by UNESCO as a part of the historic city centre [1]. It is one of the most complex sites on the eastern Adriatic coast with various findings dating from late antiquity to the early modern period. Remnants of two medieval churches have been discovered under the actual Baroque cathedral during the excavations in the 1980s - the Romanesque cathedral previously known from written sources, and a newly discovered older church dating from the Early Middle Ages [2][3][4] (Fig.
1). More than 30 years after the archaeological excavations, those buildings have remained insufficiently studied, while the archaeological finds have been almost completely undocumented and unpublished. Furthermore, up to this day the documentation of the 1980s campaigns has not been systemised or made available to the wider community of scholars.

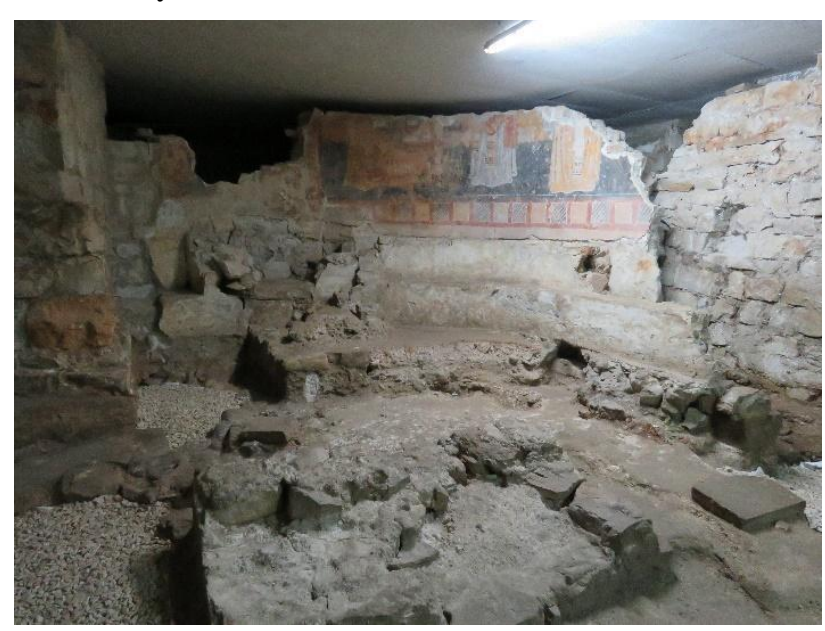

Figure 1. Area beneath the Cathedral of the Assumption of the Virgin in Dubrovnik - remnants of the chancel in the first church (photo by M. Zeman)

Participating in this project are experts from five partnering institutions: Department of Art History of the Faculty of Humanities and Social Sciences at the University of Zagreb, the Institute of Archaeology, the Institute of Art History, and the Department for Conservation and Restoration of the Academy of Fine Arts at the University of Zagreb, all collaborating with the City Parish of the Assumption in Dubrovnik (the owner of the material). Project associates, and also leaders of student workshops, from partnering institutions are: Ana Marinković, Maja Zeman and Goran Zlodi (Faculty of Humanities and Social Sciences University of Zagreb, Suzana Damiani (Academy of Fine Arts in Zagreb), Ivana Ožanić Roguljić (Institute of Archaeology in Zagreb), and Danko Zelić (Institute of Art History in Zagreb). External associates of the project are Matko Matija Marušić, Marta 
Perkić (Conservation Office, Dubrovnik), Ana Požar Piplica, Marija Šiša Vivek, and Nikolina Topić. Representing the City Parish of the Assumption in Dubrovnik, the owners of the material, the project is supervised by Ivan Viđen.

During field research in Dubrovnik, the experts from various fields, divided into four thematic research teams (stone, wall paintings, ceramics, and glass), have gathered and processed data on 2000 stone fragments, tens of thousands of wall-painting fragments, ceramic and glass finds from the site. The processing of the data from photodocumentation, plans, sketches and diaries from the 1980s excavations, all stored in the Institute of Art History [5], has also begun. From 2015 to 2020, over 40 undergraduate and graduate students of the Faculty of Humanities and Social Sciences and Academy of Fine Arts at the University of Zagreb have participated in student workshops. Students have been included in the activities of processing and digitising of the research documentation from the Institute of Art History in Zagreb (Fig. 2).

In the next chapter, the development of the database will be elaborated, after which the integration of the documentation will be presented. Since the site is multilayered, a special chapter is dedicated to the categorization of fragments in the database in order to determine their relative chronology. In the conclusion, the future activities of the project were announced - data entry for ceramics and fragments of the wall painting - which will expand and improve the integration of data on the project.

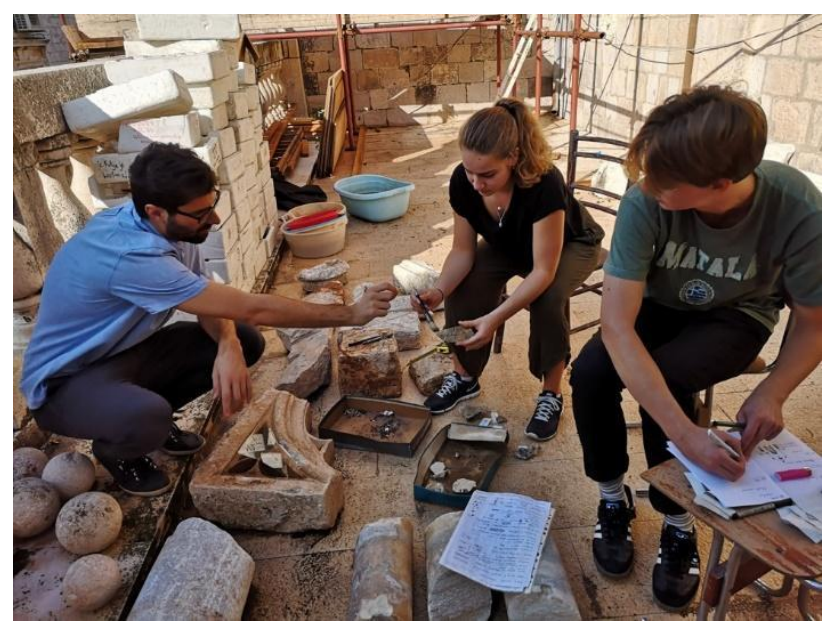

Figure 2. Working together with students on analysis and documentation of stone fragments on the roof terrace of the Cathedral (photo by M. Zeman)

\section{THE DEVELOPMENT OF THE DATABASE}

Given that the analysed movable monuments and archaeological finds are chronologically and stylistically diverse, and the documentation made in the 1980s is very complex, new methodology was needed for their interpretation. After establishing the cooperation with the Department for Information and Communication Sciences, the project activities developed towards using contemporary information and communication technology in order to enable a more complex and complete analysis of the archaeological finds, and the medieval architectural complex of the Dubrovnik Cathedral as well.

Since 2019, interactive digital tools have been in development in order to enable the use of various mechanisms of integration, comparison, annotation and visualisation of the data (metadata and digital representations of wall paintings and finds) which would allow simulation and reconstruction of the site. In addition, those mechanisms would help reconstruct the course of the previous research and the archaeological context of the architectural structures and movable finds, and thus add to interpretation of the site as a whole.

These tools are based on a key component of the information system, the database, which enables documentation and integration of gathered data, photos, plans, maps, and 3D models of architectural structures found on the site. The Modulor++ information system was chosen as the database for the project, since it is a metadata management system that enables documentation of heterogeneous cultural heritage objects. Modulor++ has event-based approach to data modelling and it is therefore flexible to exchange metadata via the LIDO schema and align with the CIDOC-CRM conceptual reference model that is adopted as standard ISO 21127:2014 - "Information and Documentation: A Reference Ontology for the Interchange of Cultural Heritage Information."

A conceptual schema was developed through the analysis of project-related specificities of entities, relationships and their properties. Based on the conceptual schema, and via the Modulor++ meta-model, the adaptation of the metadata schema in the given domain was implemented. Research and practical implementations have already shown that event-based approach to semantic metadata interoperability is appropriate and sustainable [6]. Thus, the use of some local metadata elements is enabled in this project as well, while preserving semantic interoperability in a broader heritage context.

Since 2020, intensive work has been done on entering previously gathered data on stone fragments based on field documentation (2015-2020). Students participated in structuring and systematising the existing data.

The documentation cards compiled by students contain the identification numbers, dimensions and descriptions of fragments, descriptions of motif, materials and techniques, data on the function or relationship to other architectural elements (columns, capitals, beams, ambos, ciboria), and photos. 


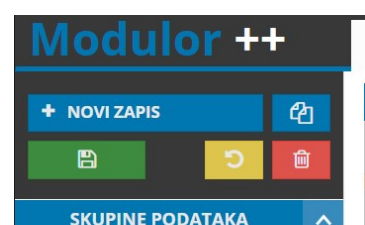

4 Vrsta/Naziv

4 Naslovi

4 Opis

4 Materijali i tehnike

4 Mjere

4 Izrada

4 Razdobje

4 Dijelovi komponente

4 Stanje

4 Natpisi i oznake

4 Nabava

4 Reference

4 Smještaj

4 |zložbe

4 Uporaba i povijes

4 Procjena

\$ Identifikacijski brojevi

4 Multimedia

4 Inventarizacija

4 Nalazišta

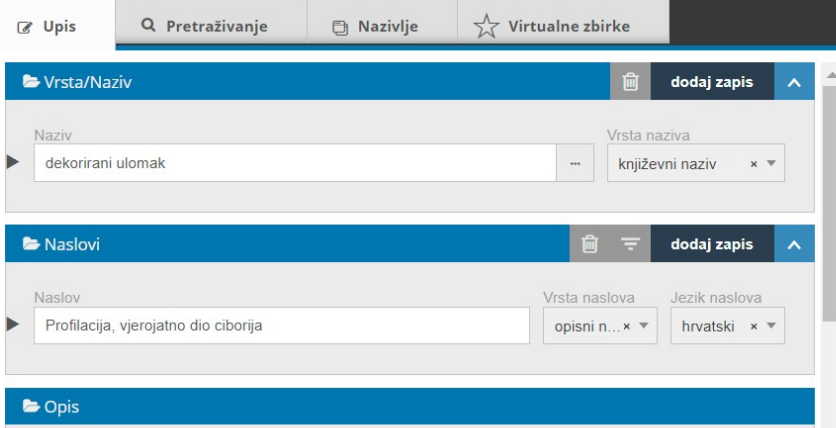

E Opis
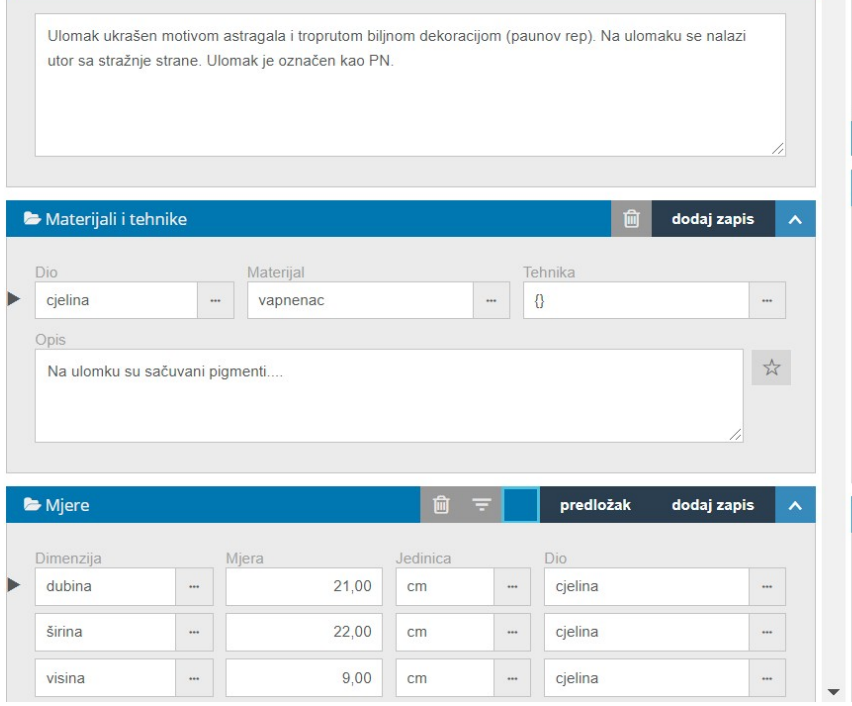

Figure 3. Data entry form - example of cataloguing a stone fragment

Students enter and edit metadata through a data entry interface (Fig. 3). For each key metadata category in the database (object type, material, technique, period, function, condition, theme, motif, etc.), relationships to corresponding concepts are established and provided via structured thesauri (Fig. 4).

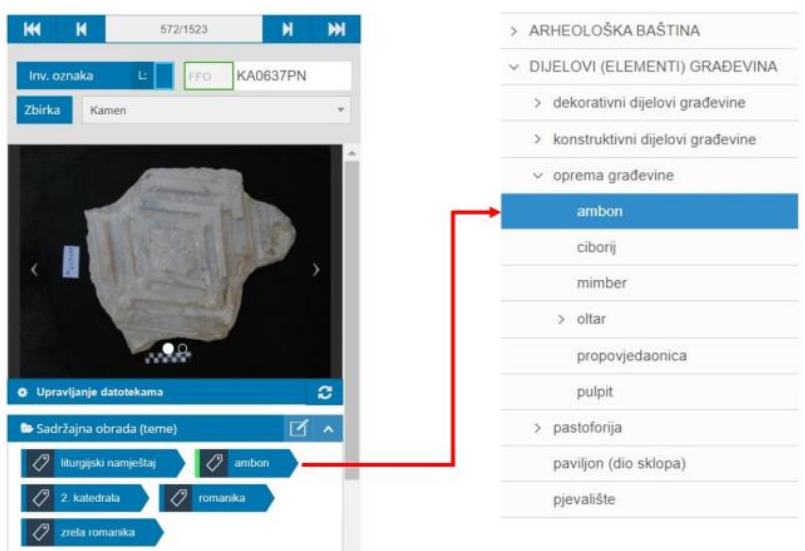

Figure 4. Work-concept relationship - example of a record for object and a record for concept (object type) in thesaurus
Thesaurus enables vocabulary control by standardisation of data values for terms used within key metadata elements. For each individual concept (e.g., ambo, marble, carving, Renaissance, etc.) there is a record in the thesaurus that unambiguously defines the concept, and one or more different terms used for the concept - the relationships between synonyms, polysemes, etc. are established. The terms are also structured in a hierarchical network, as Modulor++ supports polyhierarchical relations in the thesaurus.

References to Art \& Architecture Thesaurus (AAT) and Thesaurus of Monument Types: Data Standard in the Architectural Heritage Inventories [7] have been established for each applied concept. The thesaurus module (Fig. 5) used in the database is multilingual which will allow the publication of data in a multilingual catalogue and thus greatly contribute to the visibility of the project results. More than a hundred concepts applied in the project have already been translated in the Project of collaborative terminology contribution to the Art \& Architecture Thesaurus (AAT) held at the Faculty of Humanities and Social Sciences, University of Zagreb [8]. Important results of this project are expected also in the development and translation of the special field terminology in related interdisciplinary contexts. 


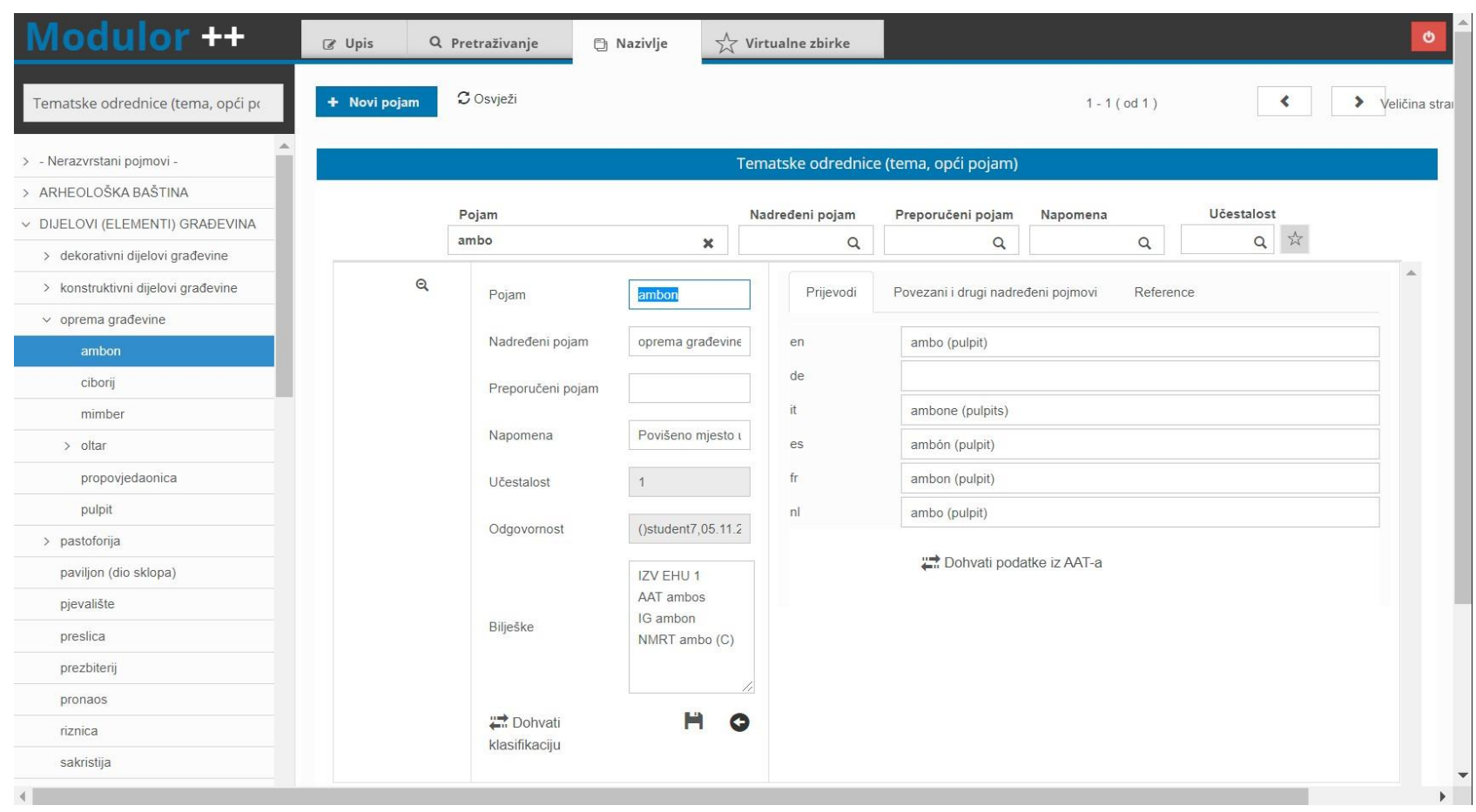

Figure 5. An example of concept record in the thesaurus

\section{INTEGRATION OF DOCUMENTATION}

The documentation made in the 1980s offers additional data on the location and the year of the finds, their context, and photographs and/or drawings of fragments made during the excavations in the 1980s, all of which are going to be integrated in the database. Student Buga Kranželić was in charge of systematising the project documentation, while student Ivan Komar was involved in the activities of structuring the data for the digital database and data entry. Irena Šimić, the documentalist at the Institute of Art History, and Danko Zelić, senior researcher at the Institute, are in charge of processing the $1980 \mathrm{~s}$ research documentation, while students Petra Galović, Ivan Komar, Buga Kranželić and Gregor Sirotić Marušić were also included in the activities.

\section{CATEGORISING THE STONE FRAGMENTS}

Since the site is multi-layered, it is important to establish categorisation of layers in the database in order to determine the relative chronology of the fragments' origin, and, if possible, a more precise dating (including the style period and/or century or decade). As the information needed for dating of stone fragments is entered into the database, attention is given to coordination and matching of this data (most importantly, aligning the chronological markers) with the data related to other materials - wall paintings, ceramics, glass, metal (numismatic finds). Further inquiry and additional analysis of the archaeological site will produce a more precise insight into the course of research conducted in the 1980s, and eventually add to the interpretation of the archaeological layers. For each object, data on quadrants, trenches, or other excavation locations, is entered into the database. This will facilitate the reconstruction of building phases, as well as their dating.

Stone fragments selected for additional analysis mostly belong to the interior of the early medieval or Romanesque church. The interactive digital database serves to group together individual collections of fragments based on data on materials, techniques, formal/stylistic features, functions and dimensions. Where appropriate, whole-part relationships between object records were established which allows simulation of certain architectural units (e.g. the Romanesque ambo). The entering of data was preceded by a mini-workshop through which the students were introduced to the basic elements of the medieval liturgical furnishing as they gathered related visual comparative material. One of the results of such grouping of material will be a visual reconstruction of particular liturgical furniture, which will provide better possibilities of comparison with other examples from the eastern Adriatic, Italy, and the larger Mediterranean area.

Thus, the visual reconstruction of the objects will enable determining the chronological layers of the analysed sculpture, as well as the workshops or even particular masters. For example, from a group of 70 preRomanesque fragments (not belonging to the same chronological layer), those belonging to a typical early medieval liturgical furnishing will be identified and their position in the ensemble will be defined (ciborium, altar rail, etc.) (Fig. 6). 


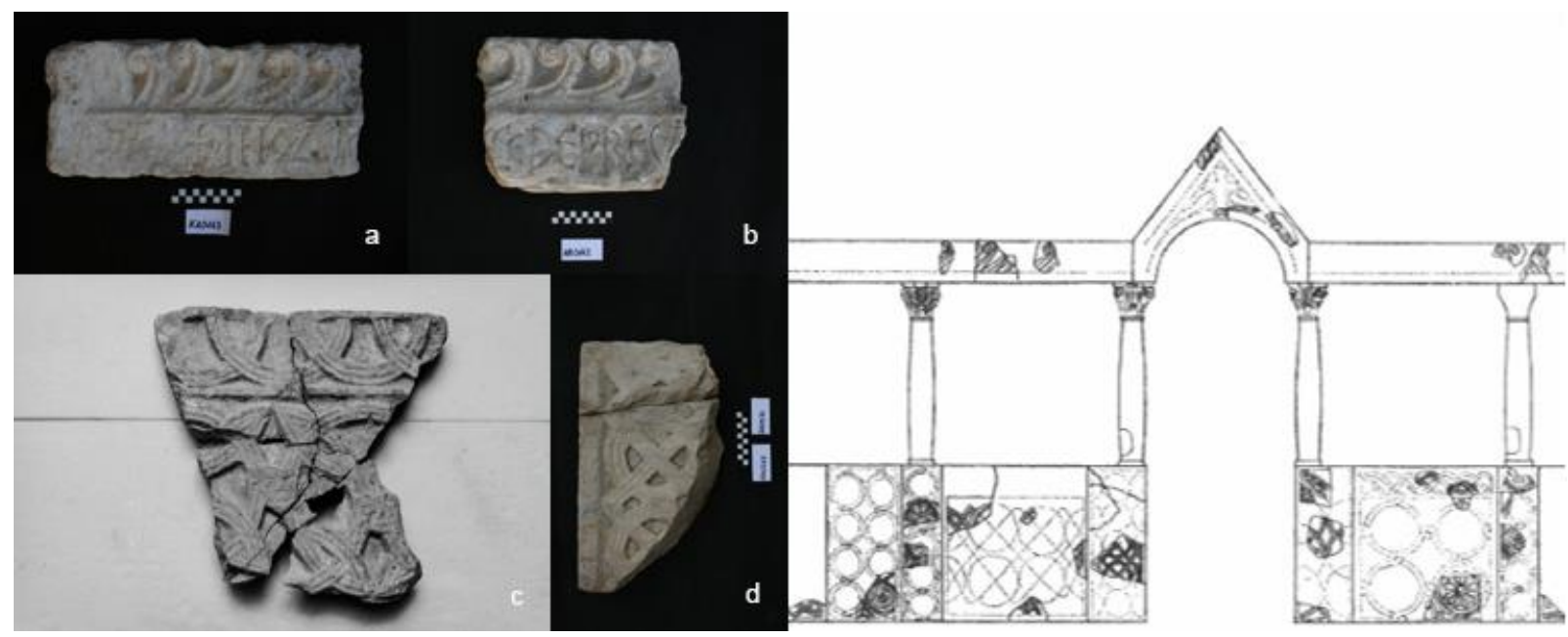

Figure 6. Fragments of pre-Romanesque altar screen of various layers from the site of the Dubrovnik Cathedral (a, b: fragments of a beam; c: fragments of a pluteus; $\mathrm{d}$ : fragment of a pilaster) (from the project documentation). Ideal reconstruction of a pre-Romanesque altar screen from Dalmatia (Mastirine, Kašić) (source: V. Delonga, 1988 [9])

Based on the analysis of 41 marble fragments recorded in the database and identified as parts of the Romanesque ambo, the general appearance of the ambo will be reconstructed. A combination of digital and comparative art-historical methods will be used for the ideal reconstruction, namely, through the comparison with the existing Romanesque ambos in the cathedral of Split and Trogir. Additional data needed for the reconstruction are provided by microscopic 3D digital inspection, a technology which detected pigments on the aforementioned marble fragments (3D digital shooting conducted by Suzana Damiani). As digital recording is used primarily in the analysis of the wall-paintings fragments, its use on the marble fragments envisages the collaboration among the research teams (Fig. 7).
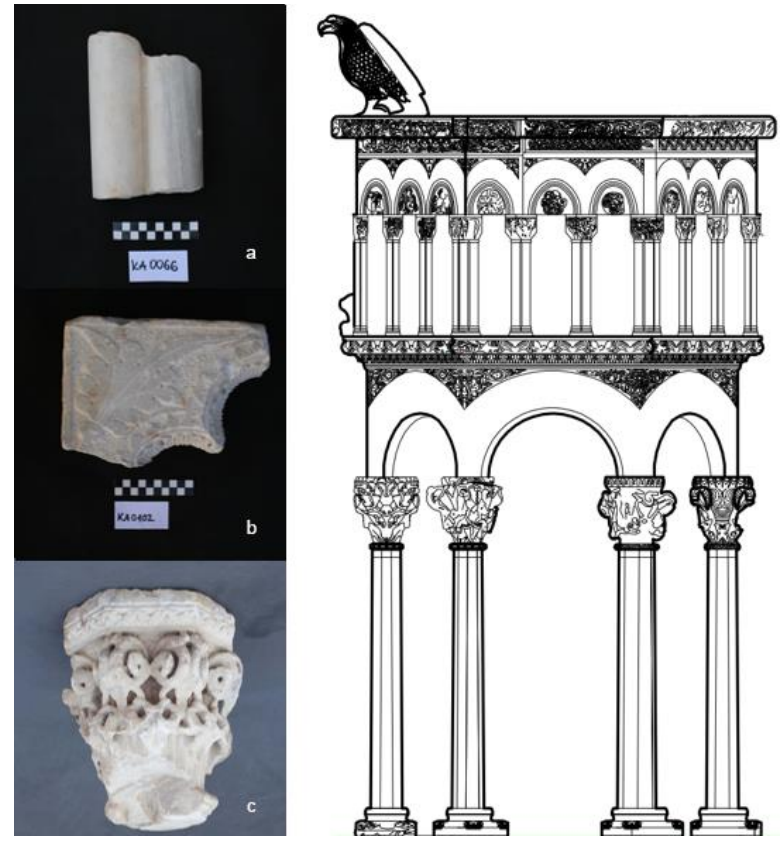

Figure 7. Marble fragments of a Romanesque ambo from the site of the Dubrovnik Cathedral (a: double column of the parapet; b: fragment of the arch; c: capital of the ambo column) (from the project documentation). Drawing of the Romanesque ambo from the Split Cathedral (source: A. Doljanin, 2018 [10])

\section{CONCLUSION}

The cataloguing and the analysis of stone fragments presented here, illustrates potentials of using digital tools in developing new methods to support the research process in the field of art history. For each object (i.e. stone fragment) metadata record is created and linked to other records representing related documentation material (field diaries, visual documentation, bibliographical references etc.), allowing complex modelling of data relations. Where appropriate, whole-part relationships between object records were established which allows for a more complete simulation and reconstruction of certain archaeological layers of the site, as well as of particular architectural units or sculptural ensembles (e.g. altar screen, Romanesque ambo).

In the next stage of the project, data for over 2000 additional stone fragments will be entered, including data for other types of movable finds from the locality ceramics and wall-painting fragments. During the process, a special field terminology related to complex interdisciplinary context will be further developed. Accordingly, the terminology will be additionally structured via multilingual thesaurus (equivalence, associative and hierarchical relationships have been established among concepts) and mapped to relevant national and international thesauri, to establish multilingual access and interoperability in the context of linked open data (LOD) environment. By implementation of FAIR principles (findability, accessibility, interoperability, and reusability) of Open Science, this project will facilitate further networking and information interlinking, and thus will represent a valuable asset for the digital art history and the multidisciplinary field of digital humanities.

\section{REFERENCES}

[1] K. Horvat-Levaj, Ed. The Cathedral of the Assumption of the Virgin in Dubrovnik, Dubrovnik - Zagreb: City Parish of the Assumption, Institute of Art History, ArTresor, 2016.

[2] J. Stošić, "Sažeti prikaz istraživanja, nalaza i problema prezentacije pod katedralom i Bunićevom poljanom u Dubrovniku," Godišnjak zaštite spomenika kulture Hrvatske, vol. 12, pp. 241-247, 1986. 
[3] J. Stošić, "Prikaz nalaza ispod katedrale i Bunićeve poljane u Dubrovniku," in Arheološka istraživanja u Dubrovniku i dubrovačkom području, Znanstveni skup Dubrovnik 1.-4. X. 1984 (Izdanja Hrvatskog arheološkog društva, vol. 12), Ž. Rapanić, Ed. Zagreb: Hrvatsko arheološko društvo, 1988, pp. 15-38.

[4] D. Zelić, "Architecture of the Old Cathedrals," in The Cathedral of the Assumption of the Virgin in Dubrovnik, K. Horvat-Levaj, Ed. Dubrovnik - Zagreb: City Parish of the Assumption, Institute of Art History, ArTresor, 2016, pp. 31-43.

[5] M. Zeman, A. Marinković, I. Ožanić Roguljić, M. Šiša Vivek, and S. Damiani, "Preliminarna analiza rezultata aktivnosti istraživačkoedukacijskog projekta Otkrivanje starih dubrovačkih katedrala (2018. - 2020.)," Annales Instituti Archaeologici, vol. XVI, no. 1, 2020, pp. 269-282.

[6] T. Ruotsalo and E. Hyvönen, "An event-based approach for semantic metadata interoperability," in The Semantic Web. ISWC 2007, ASWC 2007. Lecture Notes in Computer Science, vol. 4825,
K. Aberer et al., Eds. Berlin - Heidelberg: Springer, 2007, pp. 409_ 422.

[7] L. Križaj, Tezaurus spomeničkih vrsta: podatkovni standard u inventarima graditeljske baštine. Zagreb: Ministarstvo kulture RH, Uprava za zaštitu kulturne baštine, 2017.

[8] G. Zlodi, T. Ivanjko, P. Štefičar, and M. Marochini, "The Model of Collaborative Terminology Contribution to the Art \& Architecture Thesaurus: Application and Improvement of Crowdsourcing Methods in an Educational Context," in 2020 43rd International Convention on Information, Communication and Electronic Technology (MIPRO), Opatija, Croatia, 2020, p. 722, doi: 10.23919/mipro48935.2020.9245204.

[9] V. Delonga, "Starohrvatska crkva na 'Mastirinama' u Kašiću kod Zadra," Starohrvatska prosvjeta, vol. III, no. 18, p. 70, 1988.

[10] A. Doljanin, "Romanička propovjedaonica u katedrali sv. Dujma u Splitu - istraživanja i konzervatorskorestauratorski zahvati," Klesarstvo i graditeljstvo, vol. XXVIII, no. 1-2, p. 45, 2018. 